\title{
Interrelationships among Thyroxine, Growth Hormone, and the Sympathetic Nervous System in the Regulation of 5'- lodothyronine Deiodinase in Rat Brown Adipose Tissue
}

\author{
J. Enrique Silva and P. Reed Larsen \\ Howard Hughes Medical Institute Laboratory, Department of Medicine, Brigham and Women's Hospital \\ and Harvard Medical School, Boston, Massachusetts 02115
}

\begin{abstract}
Thyroxine $\left(\mathrm{T}_{4}\right)$ and reverse triiodothyronine are potent inhibitors of brown adipose $\mathrm{T}_{4} 5^{\prime}$-deiodinase (BAT 5'D). This effect does not require protein synthesis and is due to an acceleration of the rate of disappearance of the enzyme. Growth hormone (GH) also inhibits BAT 5'D but by a mechanism mediated through a long-lived messenger that correlates with growth rate. This explains the failure of BAT 5'D to increase abruptly after thyroidectomy as does the type II 5'-deiodinase in pituitary and central nervous system or the BAT 5'D itself after hypophysectomy. Although virtually inactive when given acutely, triiodothyronine replacement partially reduces BAT 5'D in hypophysectomized and thyroidectomized (Tx) animals probably as a result of improvement of systemic hypothyroidism and an increase in $\mathbf{G H}$ levels in the $\mathbf{T x}$ rats. The fine balance between these inhibitory factors and the stimulatory effects of the sympathetic nervous system suggests an important physiologic role for the enzyme in this tissue.
\end{abstract}

\section{Introduction}

Abundant evidence suggests that triiodothyronine $\left(\mathrm{T}_{3}\right)^{1}$ largely accounts for the thyromimetic action of the thyroidal secretion at the cellular level. Cellular $\mathrm{T}_{3}$ may come from the plasma pool or can be made in situ by $5^{\prime}$-deiodination of thyroxine $\left(T_{4}\right)$. The relative importance of these two sources varies from one tissue to another (1). On one end of the spectrum are kidney, heart and skeletal muscles in which $>90 \%$ of the $T_{3}$ comes from plasma and, at the other, is the cerebral cortex where $80 \%$ of the $T_{3}$ is made in situ. Because $\sim 50 \%$ of the circulating $T_{3}$ in the rat $(2,3)$ and $75 \%$ in humans (4) is produced from extrathyroidal 5 -deiodination of $T_{4}$, the latter reaction is essential for the maintenance of the concentration of $T_{3}$ in the tissues, regardless of the source.

The 5 -deiodination of $\mathrm{T}_{4}$ is a reaction catalyzed by, at least, two types of enzymes. The type I deiodinase (5'D-I) is most abundant in liver and kidney (5-8). This enzyme exhibits "ping-

\section{Address reprint requests to Dr. Silva. \\ Received for publication 19 July 1985}

1. Abbreviations used in this paper: BAT, brown adipose tissue; bGH, bovine growth hormone; BW, body weight; 5'-D-I, type I 5'-deiodinase; 5'-D-II, type II 5'-deiodinase; DTT, dithiothreitol; GH, growth hormone; $\alpha$-GPD, $\alpha$-glycerophosphate dehydrogenase; IGF, insulinlike growth factor; MMI, methimazole; NE, norepinephrine; PTU, propylthiouracil; $\mathrm{rT}_{3}$, reverse triiodothyronine; $\mathrm{T}_{3}$, triiodothyronine; $\mathrm{T}_{4}$, thyroxine.

J. Clin. Invest.

(c) The American Society for Clinical Investigation, Inc. $0021-9738 / 86 / 04 / 1214 / 10 \quad \$ 1.00$

Volume 77, April 1986, 1214-1223 pong" type kinetics, is highly sensitive to uncompetitive inhibition by propylthiouracil (PTU) $(5,7,8)$, is decreased in hypothyroidism, and is increased in hyperthyroidism (9). This enzyme accounts for $\sim 60-70 \%$ of the extrathyroidally produced $\mathrm{T}_{3}$ in euthyroid rats (10-15). The type II $5^{\prime}$-deiodinase (5'D-II) exhibits "sequential" type kinetics, has markedly lower apparent $K_{\mathrm{m}}$ for $\mathrm{T}_{4}$ and reverse $\mathrm{T}_{3}\left(\mathrm{rT}_{3}\right)$ than does $5^{\prime} \mathrm{D}-\mathrm{I}$ and, in addition, at variance with $5^{\prime} \mathrm{D}-\mathrm{I}, \mathrm{T}_{4}$ is the preferred substrate for this enzyme $(13,14)$. $5^{\prime} \mathrm{D}$-II is present in central nervous system, anterior pituitary gland, in brown adipose tissue (BAT) (16), and in rat and human placenta (17). Other essential characteristics of this enzyme are its marked increase in hypothyroid animals, the lack of significant inhibition by PTU in vivo, and its acute inhibition by $\mathrm{T}_{4}, \mathrm{rT}_{3}$ and, to a lesser extent, by $\mathrm{T}_{3}$ itself (18). In the cerebral cortex and in the anterior pituitary of normal rats, this enzyme accounts for all the $T_{3}$ generated in situ (15).

Although during the neonatal period the CNS 5'D-II might contribute to the serum $T_{3}$ pool (19), both the anterior pituitary and the CNS deiodinases are generally a local source of $T_{3}$. In contrast, BAT $5^{\prime} \mathrm{D}$-II not only is a major source of $\mathrm{T}_{3}$ for this tissue, but it can contribute significantly to the plasma pool of $\mathrm{T}_{3}$ when highly activated, and/or when the BAT mass is appropriately large. For example, in hypothyroid rats, extrathyroidal $\mathrm{T}_{3}$ production is insensitive to PTU but very sensitive to inhibition by either $T_{4}$ or $\mathrm{rT}_{3}(20,21)$, suggesting that $T_{3}$ is being generated via a type II 5 '-deiodinase. During the neonatal period, when BAT is a larger fraction of the total body weight, $80 \%$ of the extrathyroidally produced $T_{3}$ in euthyroid rats originates via a type II 5'-deiodinase (20). More recently, we have found that BAT 5'D-II can be stimulated markedly by the sympathetic nervous system (22), which is reflected in greater contributions of $5^{\prime} \mathrm{D}$-II to the plasma pool of $\mathrm{T}_{3}$ and, further, by parallel changes in the locally-produced BAT $\mathrm{T}_{3}(23)$. The blockade of sympathetic stimulation by the $\alpha_{1}$-antiadrenergic agent prazosin blunts the sympathetic-induced increase in enzyme activity and, also, the increments in serum and BAT $\mathrm{T}_{3}$. The parallelism between enzyme activity, plasma $T_{3}$, and locally produced $T_{3}$ in BAT suggests that this tissue may be an important source of the plasma $\mathrm{T}_{3}$ generated via $5^{\prime} \mathrm{D}-\mathrm{II}$ pathways. As much as $40-50 \%$ of the peripheral $T_{3}$ production in adult euthyroid rats $(15,21)$ and $80 \%$ in neonatal rats (19), could be generated through this pathway.

Thyroid hormone increases oxygen consumption and calorigenesis, as does stimulated BAT, but the relationships between thyroid hormone and BAT activity are largely unknown. A current hypothesis is that thyroid hormone has primarily a permissive role for the sympathetic activation of BAT (24). The existence of BAT $5^{\prime} \mathrm{D}-\mathrm{II}$, which increases both extrathyroidal and intracellular $T_{3}$, suggests that the relationship may be more complex. As is the case in CNS and pituitary, BAT 5'D-II is markedly increased in hypothyroid rats (16). In addition, and 
at variance with observations in the CNS and pituitary, BAT 5 'D-II is stimulated by the sympathetic nervous system. The studies to be described, as well as others in progress, suggest that ${ }^{\prime} \mathrm{D}-\mathrm{II}$ in BAT is under complex endocrinologic and metabolic regulation. The present report describes the effects of thyroid hormone on BAT 5'D-II, and details the interactions between thyroid hormone and the sympathetic nervous system. The results also demonstrate the growth hormone $(\mathrm{GH})$ is an important regulator of the enzyme in this tissue.

\section{Methods}

Animals. Male Sprague-Dawley rats (Charles River Breeding Laboratories, Inc., Wilmington, MA or Zivic-Miller Laboratories, Allison Park, PA) were used throughout. Except for some studies in chronic thyroidectomized rats and others, indicated when appropriate, most were performed in rats weighing 100-150 g. Hypothyroidism was induced by surgical thyroidectomy (Zivic-Miller) or by the administration of $0.02 \%$ methimazole (MMI) in the drinking water. Thyroidectomy was followed by parathyroid reimplant (Zivic-Miller). Hypophysectomized rats were obtained from Charles River Breeding Laboratories within $24 \mathrm{~h}$ of surgery. Rats were maintained in a temperature-regulated room $\left(22-25^{\circ} \mathrm{C}\right)$ with cycles of light and darkness of 14 and $10 \mathrm{~h}$, respectively. Hypophysectomized rats were given $5 \%$ glucose in the drinking water and, when indicated, corticosterone, $0.5 \mathrm{mg} / 100 \mathrm{~g}$ body weight (BW) intraperitoneally or subcutaneously. Studies in progress show that glucose is a permissive factor for elevation of BAT 5'D-II after a variety of stimuli, but $5 \%$ glucose in the drinking water does not have a stimulatory effect on BAT 5'D-II in intact or acutely thyroidectomized rats. Corticosterone has no effect on BAT 5'D-II activity and it was used to protect the animals from the stress of the experiments.

The various experimental protocols as well as doses and route of injection are described in Results.

Hormones. $\mathrm{T}_{4}$ and $\mathrm{T}_{3}$ were obtained from Sigma Chemical Co., (St. Louis, MO) and were dissolved in $10 \%$ rat serum in $0.9 \% \mathrm{NaCl}$ and injected subcutaneously or intravenously, as indicated. $\mathrm{rT}_{3}$ was purchased from Henning (West Berlin, Federal Republic of Germany). Bovine GH (NIH-GH-B18) and rat GH were kindly provided by the National Pituitary Agency. Bovine GH (bGH) was injected intraperitoneally or subcutaneously as indicated dissolved in $0.01 \mathrm{NaHCO}_{3}$, as suggested by the National Pituitary Agency. The biological activity was $3.2 \mathrm{U} / \mathrm{mg}$; it contained $1-4 \%$ prolactin activity but negligible luteinizing hormone, folliclestimulating hormone, thyroid-stimulating hormone (TSH), and adrenocorticotropin (ACTH). Either corticosterone or corticosterone-acetate were obtained from Sigma Chemical Co., dissolved in 5-10\% ethanol in 5\% dextrose and injected intraperitoneally or subcutaneously, as indicated. $\left[{ }^{125} \mathrm{I}\right] \mathrm{T}_{4},\left[{ }^{125} \mathrm{I}\right] \mathrm{T}_{3}$, and $\left[{ }^{125} \mathrm{I}\right] \mathrm{r} \mathrm{T}_{3}$ were labeled as described previously $(25,26)$ and used either for in vivo experiments or radioimmunoassays. Norepinephrine (NE) (Sterling Drugs Inc., New York), was obtained from the local pharmacy, diluted to $400 \mu \mathrm{g} / \mathrm{ml}$ in $5 \%$ glucose, and injected subcutaneously. Other drugs used were prazosin, the kind gift of Pfizer Laboratories (E. Weiss, Pharmaceutical Div.) and cycloheximide (Calbiochem-Behring Corp., San Diego, CA). Both drugs were dissolved and injected as described previously $(22,27)$.

Analytical methods. 5'D-II was measured as described previously $(15,16)$ at $2 \mathrm{nM} \mathrm{rT}_{3}$ or $1 \mathrm{nM} \mathrm{T}_{4}$ (approximately $K_{\mathrm{m}}$ concentrations) in the presence of $20 \mathrm{mM}$ dithiothreitol (DDT) and $1 \mathrm{mM}$ of PTU. Because the PTU sensitivity of this enzyme in vitro is influenced by the DTT concentration (28), we performed experiments to see whether varying the assay conditions would affect the magnitude of the physiologic responses. To this purpose, groups of rats were injected with NE $40 \mu \mathrm{g} /$ $100 \mathrm{~g} \mathrm{BW}$ and killed 2 and $4 \mathrm{~h}$ later. The BAT was removed and the enzyme activity in the controls and in the experimental groups measured at $20 \mathrm{mM}$ DTT/1 mM PTU (our standard assay conditions), $5 \mathrm{mM}$ DTT/1 mM PTU, and $10 \mathrm{mM}$ DTT/10 mM PTU. In both basal and stimulated BAT, type II activity decreased as the DTT/PTU ratio de- creased with a maximum depression of $40-50 \% .2 \mathrm{~h}$ after NE, 5'D-II was respectively: $157 \pm 41 \%, 157 \pm 20 \%$, and $154 \pm 47 \%$ of the controls. After $4 \mathrm{~h}$ the corresponding responses were: $541 \pm 129 \%, 468 \pm 112 \%$, and $478 \pm 110 \%$. Two-way analysis of variance showed that these increments are not different, indicating that the magnitude of NE stimulation of BAT is not affected by increasing the PTU/DTT ratio. ${ }^{2}$

Because the fractional $5^{\prime}$-deiodination of $\left[{ }^{125}-I\right] T_{4}$ could be reduced by unlabeled $\mathrm{T}_{4}$ or $\mathrm{rT}_{3}$ contained in the tissue extract, we estimated the amount of $\mathrm{T}_{4}$ carried over into the assay 2 and $4 \mathrm{~h}$ after injection $1 \mu \mathrm{g}$ of $T_{4} / 100 \mathrm{~g} \mathrm{BW}$, using tracer injections. The highest concentration owing to BAT $\mathrm{T}_{4}$ was $0.16 \pm 0.02 \mathrm{nM}$ at $2 \mathrm{~h}$ after $\mathrm{T}_{4}$ injection. This increment has no effect on the 5 -deiodination assay. In cerebral cortex and pituitary assays, the tissue contributions were $<0.10 \mathrm{nM}$. As previously reported, the amount of $\mathrm{rT}_{3}$ carried over into the assay is also negligible (29).

$\alpha$-Glycerophosphate dehydrogenase ( $\alpha$-GPD) was measured as described earlier (30-33) and serum $\mathrm{T}_{4}$ and $\mathrm{T}_{3}$ by radioimmunoassay (33). The rat GH radioimmunoassay used NIADDK-rat GH-I-5 for iodination and GH-RP-2 as reference. The latter gives serum concentrations that are $40 \%$ that obtained with RP-1 (expressed as nanograms per milliliter). These materials were provided by the National Pituitary Agency. Because of the variability of basal serum levels, we stimulated GH release with pentobarbital (34).

Statistical analysis. Data were analyzed by Student's $t$ test, one-way (AOV) and two-way (TWAOV) analysis of variance, multiple comparison (Neuman and Keuls test), and linear correlation of transformed or untransformed data (35).

\section{Results}

Responses of BAT 5'D-II to $T_{4}, r T_{3}$, and $T_{3}$ in chronically hypothyroid rats. These experiments were performed at least 2 mo after the surgical thyroidectomy. Studies by Obregon et al. (Obregon, Larsen, Silva, manuscript in preparation) show $>90 \%$ suppression of BAT $5^{\prime} \mathrm{D}$-II between 4 and $8 \mathrm{~h}$ after the injection of $30 \mu \mathrm{g} \mathrm{rT}_{3} / 100 \mathrm{~g} \mathrm{BW}$, and preliminary studies with $\mathrm{T}_{4}$ showed $88 \pm 1 \%$ suppression at $4 \mathrm{~h}$ and $95 \pm 1 \%$ at $8 \mathrm{~h}$ after the injection of $2 \mu \mathrm{g} / 100 \mathrm{~g} \mathrm{BW}$. Therefore, we tested the response to various doses of these iodothyronines $6 \mathrm{~h}$ after the intravenous injection. Fig. 1 shows that both the BAT and the cerebral cortical 5'D-II activities respond in the same fashion to the acute injection of $\mathrm{T}_{4}$, with $50 \%$ suppression of the basal activity at a dose of $\sim 0.2$ $\mu \mathrm{g} / 100 \mathrm{~g} \mathrm{BW}$ for both tissues. BAT 5 'D-II was also very sensitive to $\mathrm{rT}_{3}$ injection with the half-maximal suppressive dose $\sim 4.5$ $\mu \mathrm{g} / 100 \mathrm{~g} \mathrm{BW}$, but was barely affected by the injection of $40 \mu \mathrm{g} /$ $100 \mathrm{~g} \mathrm{BW} \mathrm{T}_{3}$ (Fig. 2). Similar responses of cerebral cortex 5'DII to these iodothyronines have been reported previously (18). Because of the markedly lower sensitivity of the enzyme to $T_{3}$, a complete dose response curve to this hormone was not performed.

Effect of $T_{4}$ and $T_{3}$ on the cold-stimulated BAT 5'D-II. Groups of four to five normal rats were exposed to $4^{\circ} \mathrm{C}$ for $21 \mathrm{~h}$, which stimulates the enzyme maximally. At the end of the cold exposure, the animals were injected with $1 \mu \mathrm{g} \mathrm{T}_{4} / 100 \mathrm{~g} \mathrm{BW}$ (or its vehicle), intravenously. Another group of rats received prazosin to prevent further stimulation of the enzyme by persistent norepinephrine release. The dosage was $0.4 \mathrm{mg} / 100 \mathrm{~g} \mathrm{BW}$ intraperitoneally followed by $0.2 \mathrm{mg} / 100 \mathrm{~g} \mathrm{BW} 2 \mathrm{~h}$ later (22). The remaining animals received the corresponding vehicle with

2. These results confirm the findings by Goswami and Rosenberg (28) that at lower DTT concentrations it is possible to demonstrate PTU inhibition of the BAT deiodinase. However, the concentrations of PTU necessary to decrease the $V_{\max }$ by $50 \%$ are still $300-1,000$-fold higher than those reported to reduce the $V_{\max }$ of 5'D-I a comparable degree. 


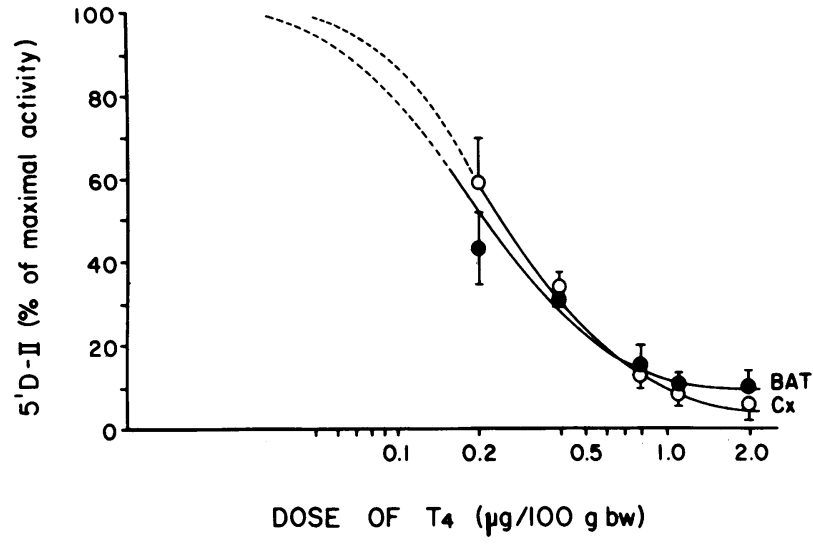

Figure 1. Response of cerebrocortical and brown adipose tissue type II $5^{\prime}$-deiodinase (5'D-II) to $T_{4}$ in rats with long-term hypothyroidism. Rats thyroidectomized $>8$ wk prior to the experiments were injected intravenously with the indicated doses of $T_{4}$ and killed $6 \mathrm{~h}$ later to measure 5'D-II in both tissues. Curves were calculated from the best fit to the linear transformation of the data $(r=>0.99$ for both tissues); the dotted part of the line denotes visual extrapolation. The calculated $\mathrm{ED}_{50}$ were, in $\mu \mathrm{g}$ of $\mathrm{T}_{4} / 100 \mathrm{~g} \mathrm{BW}, 0.22$ for the cortex $(\mathrm{Cx})$ and 0.23 for BAT.

identical timing. BAT 5'D-II activity was measured at the time of terminating the cold exposure or $4 \mathrm{~h}$ later. The results are shown in Fig. 3. The marked elevation of 5'D-II persisted over the $4 \mathrm{~h}$ after the cold stress and was not affected by prazosin, indicating no further adrenergic stimulation. In contrast, the intravenous injection of $1 \mu \mathrm{g} \mathrm{T} / 100 \mathrm{~g} \mathrm{BW}$ induced a marked reduction of the enzyme with return to near basal levels.

To characterize further the effect of $\mathrm{T}_{4}$ on cold-induced activation of BAT 5'D-II, groups of normal animals were given single injections of $1 \mu \mathrm{g} \mathrm{T}_{4} / 100 \mathrm{~g} \mathrm{BW}$ at various times before $4 \mathrm{~h}$ cold stress and killed at the end of the cold exposure (Fig. 4). The $4 \mathrm{~h}$ of cold stress induced a marked increment in the enzyme activity in the control rats, as shown by the hatched area. The injection of $T_{4}$ had a suppressive effect on the response

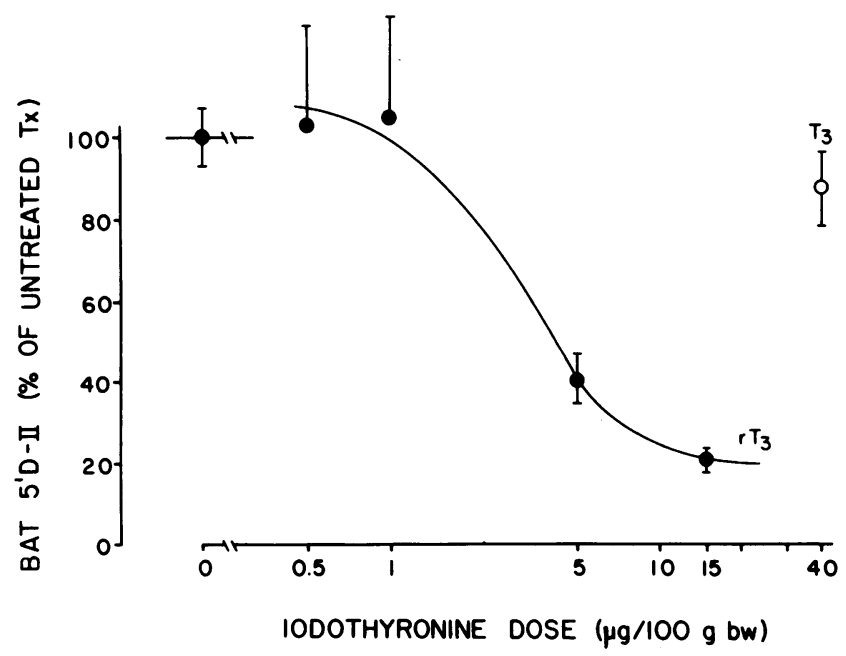

Figure 2. Response of brown adipose tissue 5'-deiodinase (BAT 5'D-II) to $\mathrm{rT}_{3}$ and $\mathrm{T}_{3}$ in rats with long-term hypothyroidism. The indicated doses of these iodothyronines were injected intravenously. The calculated $\mathrm{ED}_{30}$ was $4.5 \mu \mathrm{g}$ of $\mathrm{rT}_{3} / 100 \mathrm{~g} \mathrm{BW}(r=0.986)$.

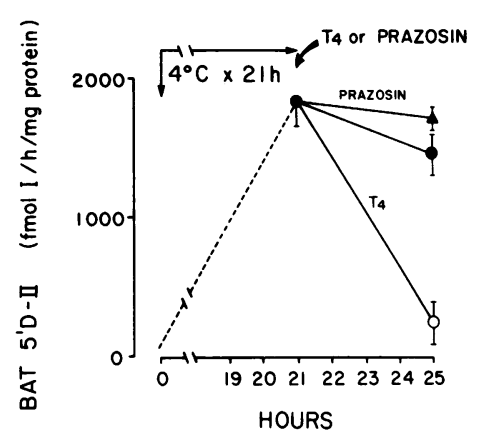

Figure 3. Effect of $\mathrm{T}_{4}$ on cold-stimulated brown adipose tissue type II 5'-deiodinase (BAT 5'D-II). Euthyroid rats were placed in the cold room overnight $(21 \mathrm{~h})$ and divided in three four-rat groups injected with either vehicle, prazosin or $T_{4}$ as indicated in Methods. 5 '-Deiodinase activity was measured after $4 \mathrm{~h}$ at room temperature.

when given at $-4 \mathrm{~h}$ and just prior to cold exposure. There was no effect of $\mathrm{T}_{4}$ given $16 \mathrm{~h}$ prior to cold stress. These results were mirrored by the serum $T_{4}$ concentrations. This was normal in the animals injected at $-20 \mathrm{~h}$, whereas in those injected at -8 or $-4 \mathrm{~h}$, it was $\sim 70$ and $100 \%$ greater than in the uninjected controls. These results indicate that the effect of $T_{4}$ is not mediated by a long-lived messenger, but could be related to an effect of $\mathrm{T}_{4}$ requiring its presence in the tissue. As indicated in Methods, these results cannot be attributed to dilution of the substrate in the assay by $\mathrm{T}_{4}$ contained in the tissue preparation.

In agreement with the poor suppression by $\mathrm{T}_{3}$ of the elevated BAT 5'D-II in hypothyroid animals, this hormone did not affect the response to $4 \mathrm{~h}$ of cold exposure in euthyroid animals (Fig. 5). Furthermore, $T_{3}$-induced hyperthyroidism augmented the response to sympathetic stimulation, e.g., to the injection of norepinephrine (Table I). This effect of $T_{3}$ resulted in part from the fall in serum $T_{4}$ subsequent to the $T_{3}$-induced suppression of TSH, since the injection of sufficient $\mathrm{T}_{4}$ to maintain its serum concentration, together with the $T_{3}$, prevented the increased response. However, another part of the effect was related to the hyperthyroidism, in that the response to $\mathrm{NE}$ in rats injected with $0.6 \mu \mathrm{g}$ of $\mathrm{T}_{3} / 100 \mathrm{~g} \mathrm{BW}$ was only $25 \%$ of that seen in rats injected with $50 \mu \mathrm{g}$ of $\mathrm{T}_{3} / 100 \mathrm{~g} \mathrm{BW} 18 \mathrm{~h}$ prior to the NE challenge. In

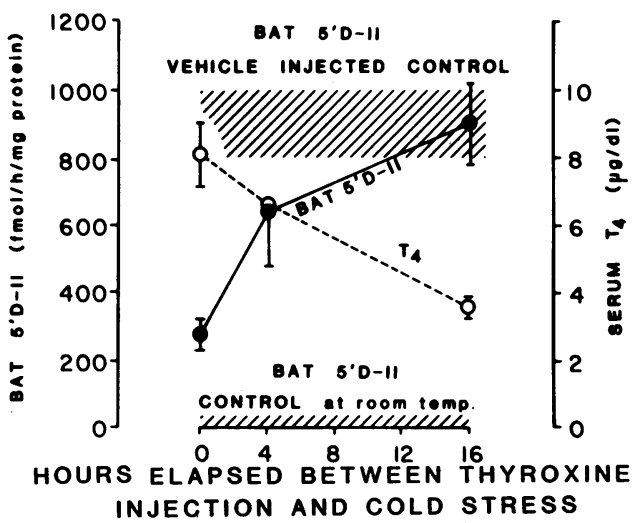

Figure 4. Dissipation of the inhibitory effect of $\mathrm{T}_{4}$ on brown adipose tissue 5'-deiodinase (BAT 5'D-II) response to cold stimulation. Euthyroid rats were injected intravenously with $1 \mu \mathrm{g}$ of $\mathrm{T}_{4} / 100 \mathrm{~g} \mathrm{BW}$ and at various times thereafter they were placed in the cold room for $4 \mathrm{~h}$. BAT 5'-deiodinase activity was measured at the end of this period. The abscissa indicates the time elapsed $(h)$ between the $T_{4}$ injection and the beginning of the cold stress. The upper hatched area represents the response of animals injected with $\mathrm{T}_{4}$ solvent at the beginning of the cold stress and the lower area the activity of unstimulated rats. 


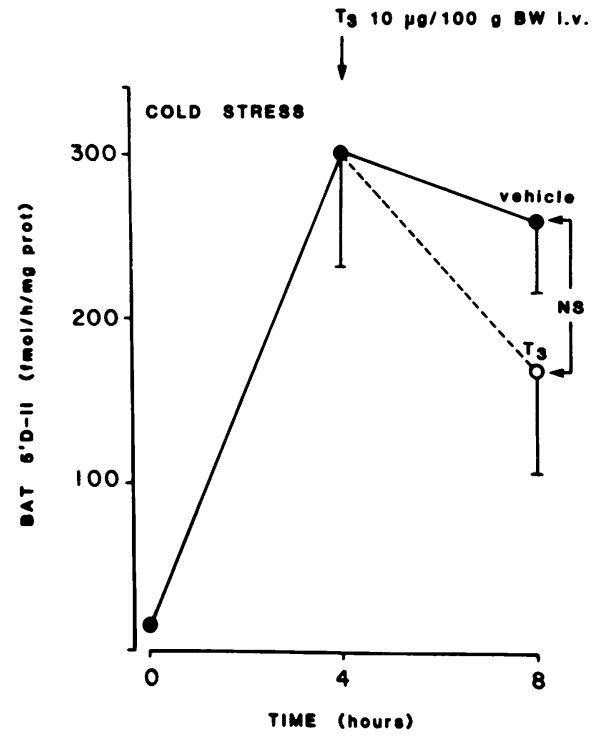

Figure 5. Effect of a large dose of $\mathrm{T}_{3}$ on cold-stimulated brown adipose tissue 5'-deiodinase (BAT 5'D-II). Euthyroid rats were placed in the cold room for $4 \mathrm{~h}$ and then injected intravenously with either $10 \mu \mathrm{g}$ of $\mathrm{T}_{3} / 100 \mathrm{~g} \mathrm{BW}$ or the vehicle. BAT 5'D-II was measured $4 \mathrm{~h}$ later; during the 4 -h interval the rats were maintained at room temperature.

both groups the serum $T_{4}$ was equally reduced to $1.5 \pm 0.3$ and $1.4 \pm 0.3 \mu \mathrm{g} / \mathrm{dl}$, respectively (experiment not shown).

We also explored the effect of cycloheximide on the $T_{4}$-induced suppression of BAT 5'D-II. Because earlier studies had shown that thyroid hormone accelerated the fractional turnover rate of the 5 'D-II in cortex and pituitary (27), we measured activity at various times after injecting cycloheximide. Groups of four to five animals were exposed to $4^{\circ} \mathrm{C}$ overnight and were then given $10 \mathrm{mg} / 100 \mathrm{~g} \mathrm{BW}$ of cycloheximide (intraperitoneally) and either $1 \mu \mathrm{g}$ of $\mathrm{T}_{4} / 100 \mathrm{~g} \mathrm{BW}$ or its vehicle intravenously. The half time of disappearance of the enzyme activity in the control animals was $\sim 100 \mathrm{~min}$ (Fig. 6), whereas in those injected with $\mathrm{T}_{4}$, the enzyme levels decreased with a half time of $\sim 35 \mathrm{~min}$ $(P<0.001)$. In pilot experiments, $5 \mathrm{mg}$ of cycloheximide/ 100 g BW had reduced $\left[{ }^{3} \mathrm{H}\right]$ leucine incorporation into TCA precipitable material by $68 \%$ in rats stimulated with NE. These results suggest that the suppressive effect of $\mathrm{T}_{4}$ on BAT 5 D-II does not require protein synthesis.

Response of BAT 5'D-II to thyroidectomy or hypophysectomy. Because BAT 5'D-II is markedly elevated in chronically hypothyroid rats, we examined BAT 5'D-II at various intervals after thyroidectomy. Much to our surprise, and in contrast to what occurs in cerebral cortex and pituitary gland, the BAT enzyme remained low for at least $9 \mathrm{~d}$ after thyroidectomy (Fig. 7). As previously reported, the deiodinase in the cerebral cortex reached the levels seen in long-term thyroidectomized rats in $\sim 2 \mathrm{~d}(36)$. In addition, this result contrasted with the rapid dissipation of the suppressive effects of $T_{4}$ on the stimulation of the enzyme induced by cold stress (Fig. 4). We therefore examined the response of BAT 5'D-II to hypophysectomy. Fig. 7 shows that the activity of the enzyme increased rapidly 3-4 $d$ after this procedure, reaching the levels seen in chronically hypothyroid rats in $\sim 5 \mathrm{~d}$. Whereas $\mathrm{T}_{4}$ was still present in serum $24 \mathrm{~h}$ after hypophysectomy $(1.8 \pm 0.2[\mathrm{SE}] \mu \mathrm{g} / \mathrm{dl})$, the concentrations were not significantly different betwen $48 \mathrm{~h}$ and 5 days after the hypophysectomy $(0.88 \pm 0.4 \mathrm{vs} 0.58 \pm 0.09 \mu \mathrm{g} / \mathrm{dl})$. The time course of the elevation after hypophysectomy, although markedly faster than after thyroidectomy, does not follow the fall in serum $T_{4}$ as closely as does the BAT $5^{\prime} \mathrm{D}$-II response to cold-stimulation (Fig. 4).

These results suggested that there is a pituitary factor that exerts a tonic inhibition on BAT 5'D-II. Because the enzyme activity ultimately reaches markedly elevated levels in chronically hypothyroid rats, one may infer that this factor could also be thyroid hormone-dependent. These observations prompted a series of experiments to define the nature of the pituitary-dependent inhibition.

Table I. Effects of $T_{3}$ Treatment, with or without $T_{4}$, on the BAT 5'D-II Response to Acute NE Injection in Normal Rats

\begin{tabular}{|c|c|c|c|c|c|}
\hline Exp. no. 176 & Treatment $(n)$ & BAT 5'D-II & Exp. no. 199 & Treatment $(n)$ & BAT 5'D-II \\
\hline & & fmol/h/mg protein & & & $\mathrm{fmol} / \mathrm{h} / \mathrm{mg}$ protein \\
\hline & None (5) & $0.98 \pm 0.15$ & & None (4) & $1.00 \pm 0.18$ \\
\hline & NE (5) & $5.14 \pm 0.99$ & & NE (4) & $6.81 \pm 1.43$ \\
\hline & $T_{3}(5)$ & $2.27 \pm 0.28$ & & & \\
\hline & $T_{3}+N E(4)$ & $9.70 \pm 1.40$ & & & \\
\hline & & & & $T_{3}+T_{4}(4)$ & $1.15 \pm 0.18$ \\
\hline & & & & $\mathrm{T}_{3}+\mathrm{T}_{4}+\mathrm{NE}(3)$ & $0.69 \pm 0.19$ \\
\hline AOV F & & 24.03 & & & 16.67 \\
\hline$P$ & & $<0.001$ & & & $<0.001$ \\
\hline$P<0.05$ by & & NE vs. control & & & NE vs. control \\
\hline Newman-Keuls test & & $T_{3}+N E$ vs. control & & & NE vs. $T_{3}+T_{4}$ \\
\hline & & $T_{3}+N E$ vs. NE & & & NE vs. $T_{3}+T_{4}+N E$ \\
\hline
\end{tabular}

All values are the mean \pm SEM expressed relative to controls (exp. no. $176=18 \pm 2$ and exp. no. $199=28 \pm 5 \mathrm{fmol} \mathrm{I} / \mathrm{h} / \mathrm{mg}$ protein). The numbers in parentheses indicate the number of rats per treatment group. Rats were injected subcutaneously either with $20 \mu \mathrm{g}$ of $\mathrm{T}_{3} / 100 \mathrm{~g} \mathrm{BW}$ (exp. no. 176) or $20 \mu \mathrm{g}$ of $\mathrm{T}_{3} / 100 \mathrm{~g} \mathrm{BW}+1.5 \mu \mathrm{g}$ of $\mathrm{T}_{4} / 100 \mathrm{~g} \mathrm{BW}$ (exp. no. 199) daily, divided in two doses, for 4 days. On the fifth day they were challenged with $40 \mu \mathrm{g}$ of NE/100 g BW subcutaneously (or its vehicle) and killed $4 \mathrm{~h}$ later. Abbreviations: NE, norepinephrine; AOV, analysis of variance; BAT 5'D-II, brown adipose tissue 5'-deiodinase activity. 


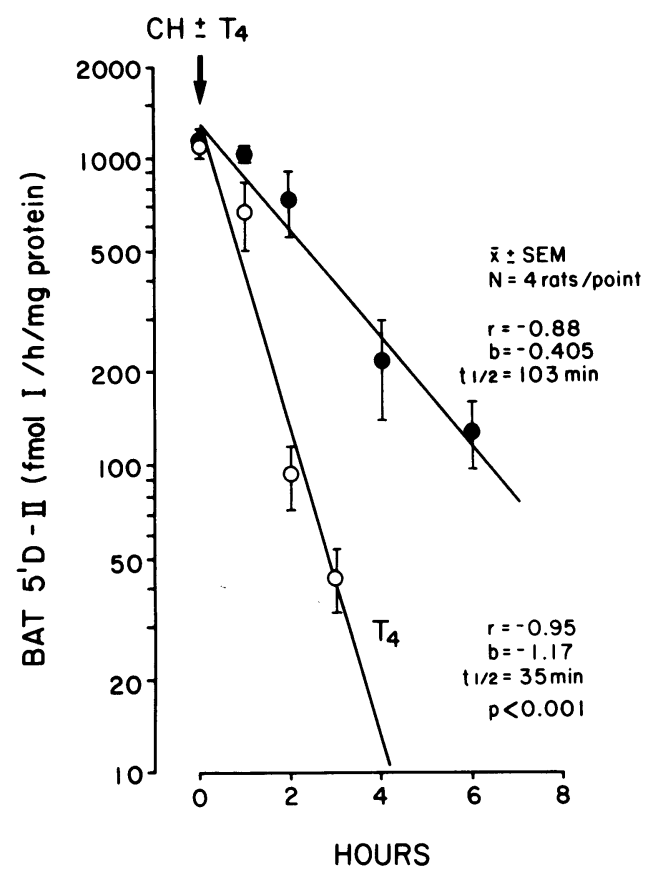

Figure 6. Effect of $\mathrm{T}_{4}$ on the fractional turnover rate of brown adipose tissue 5'-deiodinase (BAT 5'D-II). Euthyroid rats were placed in the cold room overnight $(\sim 18 \mathrm{~h})$. At the end of this period they were injected with $10 \mathrm{mg}$ of cycloheximide $(\mathrm{CH}) / 100 \mathrm{~g} \mathrm{BW}$ intravenously and with either $1 \mu \mathrm{g}$ of $\mathrm{T}_{4} / 100 \mathrm{~g} \mathrm{BW}$ or its vehicle intravenously. Groups of four rats were killed at the indicated times to measure BAT 5'D-II.

Effect of various hormone replacements on the post-hypophysectomy elevation of $B A T$ 5'D-II activity. Sexually immature males (75-100 g) were hypophysectomized and within the next $24 \mathrm{~h}$ were given one of the following hormones: corticosterone, prolactin, $b G H, T_{3}$, or $T_{4}$. All injections were given divided in 2 daily doses for $4 \mathrm{~d}$. Results are shown in Fig. 8. Corticosterone $1 \mathrm{mg} / 100 \mathrm{~g} \mathrm{BW}$ per day subcutaneously, or prolactin $0.4 \mathrm{mg} /$

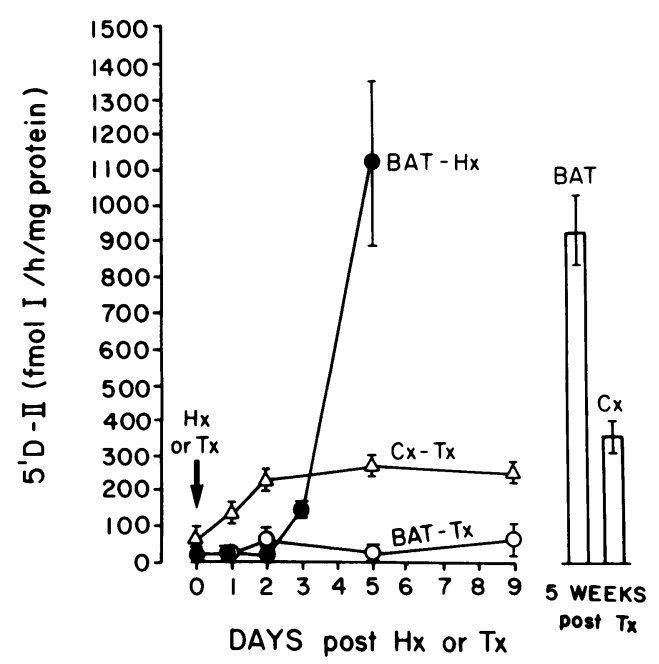

Figure 7. Responses of cerebrocortical (Cx) or brown adipose tissue (BAT) type II 5'-deiodinase (5'D-II) to thyroidectomy (Tx). Comparison with BAT 5'D-II response to hypophysectomy $(\mathrm{Hx})$. Rats were thyroidectomized by the supplier at day 0 and 5'D-II activity was followed for the indicated days. Cx and BAT 5'D-II in long-term hypothyroid rats (5 wk) are presented for comparison.

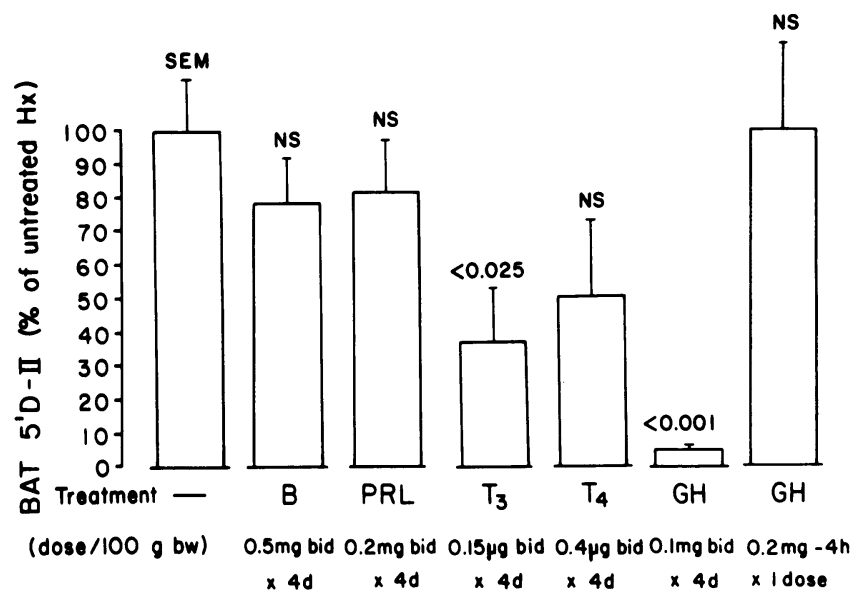

Figure 8. Effect of various hormones on the elevation of brown adipose tissue $5^{\prime}$-deiodinase (BAT 5'D-II) after hypophysectomy (Hx). Abbreviations: B, corticosterone; PRL, bovine prolactin; GH, bovine growth hormone. Rats were given the indicated treatments starting within $24 \mathrm{~h}$ of the Hx (except for GH in the last column which was given on the fifth day after $\mathrm{Hx}$ ). All values have been expressed as percentage of the response observed in hypophysectomized rats maintained on $5 \%$ glucose in the drinking water.

$100 \mathrm{~g} \mathrm{BW}$ per day, intraperitoneally, did not prevent the increase in BAT 5'D-II. Replacement doses of $\mathrm{T}_{4}(0.8 \mu \mathrm{g} / 10 \mathrm{~g} \mathrm{BW}$ per day) subcutaneously were also ineffective statistically but there was great variability in individual responses. In subsequent experiments, $\mathrm{T}_{4}$ at this dosage partially suppressed the response to hypophysectomy analogous to the effect of $0.3 \mu \mathrm{g}$ of $\mathrm{T}_{3} / 100$ g BW per day. In contrast, bGH $0.2 \mathrm{mg} / 100 \mathrm{~g} \mathrm{BW}$ per day intraperitoneally for $4 \mathrm{~d}$, but not in one dose $4 \mathrm{~h}$ prior to killing the animals, completely blunted the BAT 5 D-II response to hypophysectomy.

Although testosterone was not directly investigated, the removal of the gonadotropins can hardly account for the rapid increment of BAT $5^{\prime} \mathrm{D}-\mathrm{II}$ after hypophysectomy, in that these animals were sexually immature. Similarly, sexually immature rats and sexually mature rats, regardless of gender, exhibit equal BAT 5'D-II responses to catecholamines and cold stress (Silva, Larsen, manuscript in preparation). Experimental support for endogenous opiates being a pituitary inhibitory factor is also lacking, because the injection of naloxone $40 \mu \mathrm{g} / 100 \mathrm{~g} \mathrm{BW}$ intravenously $4.5 \mathrm{~h}$ before killing followed by two more intraperitoneal injections at -3 and $-1.5 \mathrm{~h}$, failed to elevate the BAT $5^{\prime} \mathrm{D}-\mathrm{II}$ activity in rats thyroidectomized $24 \mathrm{~h}$ previously. In summary, these findings point to GH deficiency which allows BAT $5^{\prime} \mathrm{D}-\mathrm{II}$ to rise after hypophysectomy. It is also likely that $\mathrm{GH}$ is the factor that explains the delayed increase of BAT $5{ }^{\prime} \mathrm{D}-\mathrm{II}$ following thyroidectomy. The following experiments were devised to evaluate these hypotheses.

Time course of BAT 5'D-II elevation, growth rate, and GH reduction after removal of thyroid hormone. To further our understanding of the delayed response of BAT 5 'D-II to the removal of thyroid hormone, $75-80-\mathrm{g}$ rats were given $0.02 \% \mathrm{MMI}$ in the drinking water, and serum $\mathrm{T}_{4}, \mathrm{~T}_{3}, \mathrm{GH}$ response to pentobarbital, body weight gain, and BAT $5^{\prime}$ D-II were measured after 1,2 , and 3 wk. The results are depicted in Fig. 9. They show that by 1 wk after starting MMI, the serum concentrations of $T_{4}$ and $T_{3}$ were maximally reduced. By this time the pituitary $\mathrm{GH}$, as assessed by its response to pentobarbital, was $\sim 20 \%$ of the basal 


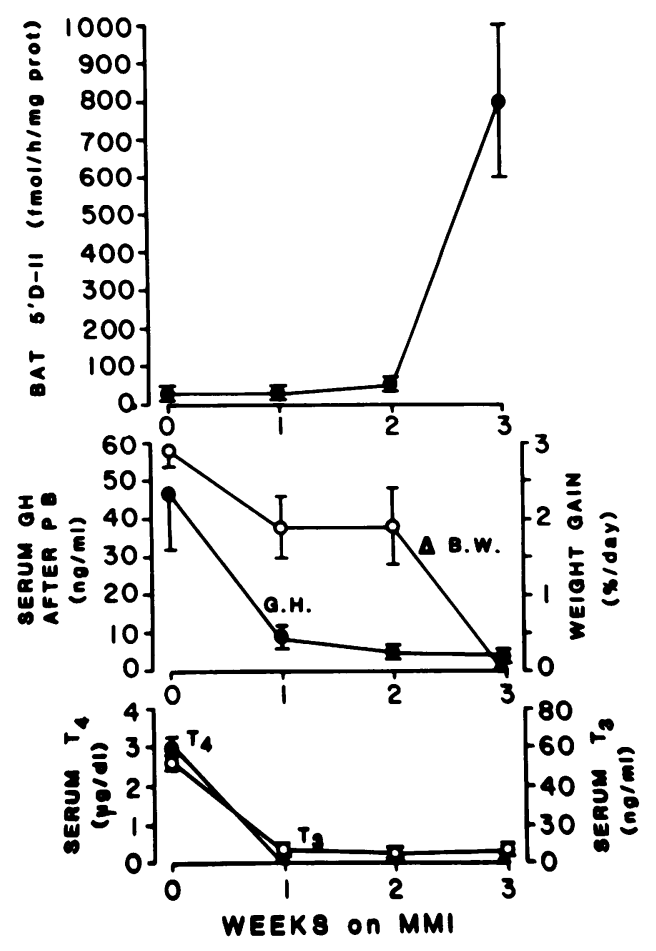

Figure 9. Time course of serum $T_{4}, T_{3}$, growth hormone, growth, and brown adipose tissue $5^{\prime}$-deiodinase (5'D-II) to antithyroid treatment. Euthyroid rats weighing $75-80 \mathrm{~g}$ were given $0.02 \%$ methimazole (MMI) in the drinking water for $3 \mathrm{w}$. (Lower panel) Serum concentrations of $\mathrm{T}_{4}$ and $\mathrm{T}_{3}$; (middle panel) serum growth hormone (GH) response to pentobarbital (PB) and the rate of body weight increase ( $\triangle \mathrm{BW})$; (upper panel) BAT 5'D-II activity.

and it continued to decrease, reaching $10 \%$ of control, after 2 wk on MMI. Body weight was measured over the last 3-4 d of each week and used as an expression of $\mathrm{GH}$ action, because rats of this age are growing rapidly. By 1 wk the mean weight gain per day was reduced by $\sim 30 \%$, (not significantly), it remained unchanged during the second week, and it ceased in the third week. The upper part of Fig. 9 shows that BAT 5'D-II remained low during the first $2 \mathrm{wk}$, but increased dramatically during the third week of MMI treatment.

Effects of $\mathrm{GH}$ and $\mathrm{T}_{3}$ in chronically hypothyroid rats. Because GH levels are reduced in chronically hypothyroid rats, we explored the effect of repeated injections of bGH on 5'D-II activities in various tissues in these rats. The results (Table II) showed that $5 \mathrm{~d}$ of bGH administration to hypothyroid rats reduced the levels of BAT 5'D-II by $40 \%$ but did not affect the levels of this enzyme in the cerebral cortex or pituitary gland.

We also explored further the partial prevention by $T_{3}$ of the increase in BAT 5'D-II activity after hypophysectomy (Fig. 7), inasmuch as this contrasts with absence of an acute effect of $T_{3}$ on hypothyroid rats or cold-stimulated BAT 5'D-II (Fig. 2, Fig. 5). One explanation for the results was that $T_{3}$ potentiated the effect of residual $\mathrm{GH}$, somatomedin $\mathrm{C}$, or other growth factors, the half-life of which was longer than that of GH itself. In this study hypophysectomized rats were maintained on $5 \%$ glucose for $5 \mathrm{wk}$. At this time, one group of animals was given 0.025 mg of bGH/100 g BW twice daily, i.e. only one-fourth of the dose used previously (Fig. 7 and Table II). Another group received $\mathrm{GH}$ plus $0.15 \mu \mathrm{g}$ of $\mathrm{T}_{3} / 100 \mathrm{~g} \mathrm{BW}$ twice daily, and a third received $T_{3}$ alone in the same dosage. The treatments lasted for $5 \mathrm{~d}$ and the results are shown in Table III. $\mathrm{T}_{3}$ alone, in a dose that normalized liver $\alpha-G P D$, caused a $40 \%$ reduction in the BAT 5'-deiodinase. GH alone caused a $60 \%$ reduction in the 5'D-II levels and, when given with $\mathrm{T}_{3}$, caused an $84 \%$ reduction of the enzyme activity. The differences among the various treatment groups were all significant by the Neuman-Keuls test, suggesting that $T_{3}$ has a modest intrinsic effect which is additive to that of GH. The significant, albeit small, effect of replacement doses of $\mathrm{T}_{3}$ in this experiment contrasts with the lack of an acute decrease in the enzyme after large doses of $T_{3}$ in chronically hypothyroid rats. This suggests that the effect of prolonged $T_{3}$ replacement on BAT 5'D-II is mediated through different mechanisms from those involved in the suppression by $\mathrm{T}_{4}$ or $\mathrm{rT}_{3}$.

Effect of $T_{3}$ replacement in long-term hypothyroid rats upon growth, hepatic $\alpha-G P D$ and BAT 5'D-II. Rats with long-term hypothyroidism were injected with $0.3 \mu \mathrm{g}$ of $\mathrm{T}_{3} / 100 \mathrm{~g} \mathrm{BW}$ per day subcutaneously for either 2 or $7 \mathrm{~d}$. The animals were weighed daily and liver mitochondrial $\alpha$-GPD and BAT 5'D-II were measured. The results are shown in Table IV. By $7 \mathrm{~d}$ of treatment weight gain increased significantly and $\alpha$-GPD was normalized. However, BAT 5'D-II was reduced only by $70 \%$, remaining severalfold higher than in control rats (for normal values see Tables II and III). The rats treated for only $2 \mathrm{~d}$ showed no significant increase in weight, an increase in $\alpha$-GPD to $\sim 30 \%$ of normal, i.e., of the rats treated for $7 \mathrm{~d}$, and no change in BAT 5'D-II. Relative to controls, the BAT 5 'D-II reduction induced by $7 \mathrm{~d}$ of $T_{3}$ in hypothyroid rats was significantly greater than that observed in hypophysectomized rats (Table III), suggesting that in

Table II. Effect of Growth Hormone Administration on 5'D-II Activity in Various Tissues from Long-Term Hypothyroid (Thyroidectomized) Rats

\begin{tabular}{|c|c|c|c|c|}
\hline & \multicolumn{4}{|l|}{ 5D-II } \\
\hline & \multicolumn{2}{|l|}{ BAT } & \multirow[b]{2}{*}{$C x$} & \multirow[b]{2}{*}{ PIT } \\
\hline & Interscapular & Perirenal & & \\
\hline & $\mathrm{fmol} / \mathrm{h} / \mathrm{mg}$ protein & $\mathrm{fmol} / \mathrm{h} / \mathrm{mg}$ protein & $\mathrm{fmol} / \mathrm{h} / \mathrm{mg}$ protein & $\mathrm{fmol} / \mathrm{h} / \mathrm{mg}$ protein \\
\hline Control $(n=5)$ & $649 \pm 76$ & $1,133 \pm 94$ & $139 \pm 27$ & $3,189 \pm 302$ \\
\hline GH $(n=6)$ & $399 \pm 71$ & $659 \pm 136$ & $177 \pm 26$ & $3,397 \pm 253$ \\
\hline$P$ & $<0.05$ & $<0.025$ & NS & NS \\
\hline
\end{tabular}

All values are the mean \pm SEM. Chronically hypothyroid rats were injected daily with $0.2 \mathrm{mg}$ of bGH/100 $\mathrm{g}$ BW (or its vehicle) for $5 \mathrm{~d}$ and killed the day after the last injection. Abbreviations: GH, growth hormone; BAT, brown adipose tissue; Cx, cerebral cortex; PIT, anterior pituitary. 
Table III. Effect of Growth Hormone, $T_{3}$, or Both, on BAT 5'D-II Activity in Long-Term Hypophysectomized Rats

\begin{tabular}{lcl}
\hline Treatment & BAT 5'D-II & Liver $\alpha$-GPD \\
\hline & fmol/h/mg protein & $(\Delta O D / m i n / m g) \times 10^{3}$ \\
Control (4) & $2,346 \pm 202$ & $16 \pm 1.4$ \\
GH (5) & $929 \pm 129$ & - \\
$\mathrm{T}_{3}(5)$ & $1,407 \pm 68$ & $43 \pm 4.7$ \\
$\mathrm{GH}+\mathrm{T}_{3}(5)$ & $372 \pm 96$ & - \\
Intact controls (4) & $68 \pm 13$ & $54 \pm 10$ \\
\hline AOV & $F=50.04$ & $F=8.82$ \\
$P$ & $<0.01$ & $<0.02$ \\
$P<0.05$ by & Control vs. rest & Cont. vs. $\mathrm{T}_{3}$ \\
\multicolumn{1}{c}{ Newman-Keuls test } & $\mathrm{T}_{3}$ vs. GH & Cont. vs. intact \\
& $\mathrm{T}_{3}+\mathrm{GH}$ vs. GH & $\mathrm{T}_{3}+\mathrm{GH}$ vs. $\mathrm{T}_{3}$
\end{tabular}

All values are the mean \pm SEM for each treatment group, the number of rats being indicated in parentheses. Rats were hypophysectomized and received 5\% glucose (see Methods) for $5 \mathrm{wk}$ before the treatments were started. Treatments consisted of GH, $0.05 \mathrm{mg} / 100 \mathrm{~g}$ BW per day subcutaneously, or $\mathrm{T}_{3}, 0.3 \mu \mathrm{g} / 100 \mathrm{~g} \mathrm{BW}$ per day subcutaneously, or both combined. Doses were divided into two daily injections and were given for $5 \mathrm{~d}$. Rats were killed the day after the last injection. During the period of treatment all hypophysectomized rats received corticosterone $0.5 \mathrm{mg} / 100 \mathrm{~g} \mathrm{BW}$ twice daily in subcutaneous injections. Abbreviations: $\mathrm{GH}$, growth hormone; $\mathrm{AOV}$, analysis of variance; BAT 5'-II, brown adipose tissue type II 5'-deiodinase; $\alpha$-GPD, alpha glycerophosphate dehydrogenase.

thyroidectomized rats part of the effect of chronic $T_{3}$ administration could be due to an increase in GH levels in the pituitary and in the serum, as observed in the present experiments (Table IV).

Response of BAT and cortex $5^{\prime} D-I I$ to $T_{4}$ withdrawal in hypophysectomized rats treated with $T_{4}$. To confirm that the failure of BAT 5'D-II to rise abruptly after thyroidectomy was due to pituitary-related mechanisms and not to one extrapituitary message induced by thyroid hormone, hypophysectomized rats were given $\mathrm{T}_{4}(0.8 \mu \mathrm{g} / 100 \mathrm{~g}$ BW per day $)$ starting $18 \mathrm{~d}$ after surgery.
Treatment was continued for 1 wk and rats were sacrificed at various times after discontinuing $T_{4}$. The results of this experiment are shown in Fig. 10. In contrast to the delayed increase in BAT 5'D-II after thyroidectomy (Figs. 7 and 10), or during MMI treatment (Fig. 9), 5'D-II activity increased at the same rate in BAT and cerebral cortex, closely reflecting the fall of serum $\mathrm{T}_{4}$.

\section{Discussion}

The present studies confirm that the BAT $5^{\prime} \mathrm{D}-\mathrm{II}$ is elevated in animals with long-term hypothyroidism and, further, that the enzyme responds to the acute injection of $T_{4}$ and $r T_{3}$ in the same manner as it does in the pituitary and the cerebral cortex. In all three tissues the enzyme is highly responsive to $T_{4}$ and $\mathrm{rT}_{3}$, and much less so to the acute injection of $\mathrm{T}_{3}$ (18). As in cerebral cortex and the anterior pituitary gland, the acute iodothyronine-mediated suppression of the enzyme activity in BAT does not require protein synthesis, and the iodothyronines appear to accelerate the disappearance or inactivation of the enzyme.

Whereas for the cerebrocortical and pituitary 5'D-II, the primary regulatory input identified to date is the serum or tissue $\mathrm{T}_{4}$ concentrations, BAT 5'D-II seems to be under a more complex control. We have reported earlier (22) that BAT 5'D-II is markedly stimulated by NE via an $\alpha-1$ receptor, a property not shared by the cerebrocortical and pituitary 5 'D-II. The present studies show that the expression of the enzyme activity depends not only on thyroid hormone and the sympathetic nervous system, but is also under the inhibitory influence of GH or GH-dependent processes. This possibility was first raised when we noted there was no immediate increase in BAT 5'D-II after thyroidectomy. Whereas the pituitary and cerebrocortical 5'D-II increased within $24-48 \mathrm{~h}$ in the same rats, 2-3 wk were required to obtain maximal levels in BAT. This long delay was not observed after hypophysectomy as maximal and similar levels of BAT 5'D-II were observed within $5 \mathrm{~d}$. When hypophysectomized animals were given various replacement hormones, only GH prevented the rise in BAT 5'D-II. This effect of GH was evident when the hormone was injected $4 \mathrm{~d}$ but not when it was given acutely on the fifth day after hypophysectomy. This finding,

Table IV. Effects of 2- or 7-d T3-Replacement Trials on Brown Adipose Tissue 5'-Deiodinase, Liver $\alpha$-Glycerophosphate Dehydrogenase, Growth, and Growth Hormone Serum Concentration in Long-Term Thyroidectomized Rats

\begin{tabular}{|c|c|c|c|c|c|c|}
\hline Treatment & BAT 5'D & $\alpha$-GPD & Weight gain & Serum GH & Serum $T_{3}$ & Serum $T_{4}$ \\
\hline & fmol/h/mg protein & $(\Delta O D / \mathrm{min} / \mathrm{mg}$ protein $) \times 10^{3}$ & $\%$ & $n g / m l$ & $n g / m l$ & $\mu g / d l$ \\
\hline A. None & $491 \pm 105$ & $7 \pm 2$ & $0.8 \pm 0.5$ & $2.8 \pm 0.4$ & $0.20 \pm 0.02$ & $0.16 \pm 0.04$ \\
\hline B. $T_{3}-2 d$ & $452 \pm 51$ & $20 \pm 2$ & $0.9 \pm 0.4$ & $12.7 \pm 4.5$ & $0.98 \pm 0.13$ & $0.10 \pm 0.03$ \\
\hline C. $T_{3}-7 \mathrm{~d}$ & $161 \pm 33$ & $60 \pm 6$ & $14.9 \pm 1.1$ & $26.3 \pm 7.2$ & $0.40 \pm 0.03$ & $0.00 \pm 0.00$ \\
\hline \multicolumn{7}{|l|}{ AOV: } \\
\hline$F$ & 6.61 & 185.20 & 120.80 & 6.51 & 26.88 & 5.23 \\
\hline$P$ & $<0.02$ & $<0.001$ & $<0.001$ & $<0.02$ & $<0.001$ & $<0.02$ \\
\hline$P<0.05$ by & C vs. A & C vs. A & C vs. A & C vs. A & C vs. A & C vs. A \\
\hline \multirow[t]{2}{*}{ Newman-Keuls test } & C vs. B & C vs. B & C vs. B & & B vs. A & C vs. B \\
\hline & & B vs. A & & & B vs. C & \\
\hline
\end{tabular}

All entries are the mean $\pm \mathrm{SEM}$ of five rats. $\mathrm{T}_{3}, 0.3 \mu \mathrm{g} / 100 \mathrm{~g} \mathrm{BW}$, was injected subcutaneously for 2 or $7 \mathrm{~d}$ as indicated. All measurements, except body weight, were performed $15-16 \mathrm{~h}$ after the last injection of $\mathrm{T}_{3}$. Abbreviations: GH, growth hormone; BAT 5'D, brown adipose tissue 5'deiodinase; $\alpha-G P D$, alpha glycerophosphate dehydrogenase; AOV, analysis of variance. 

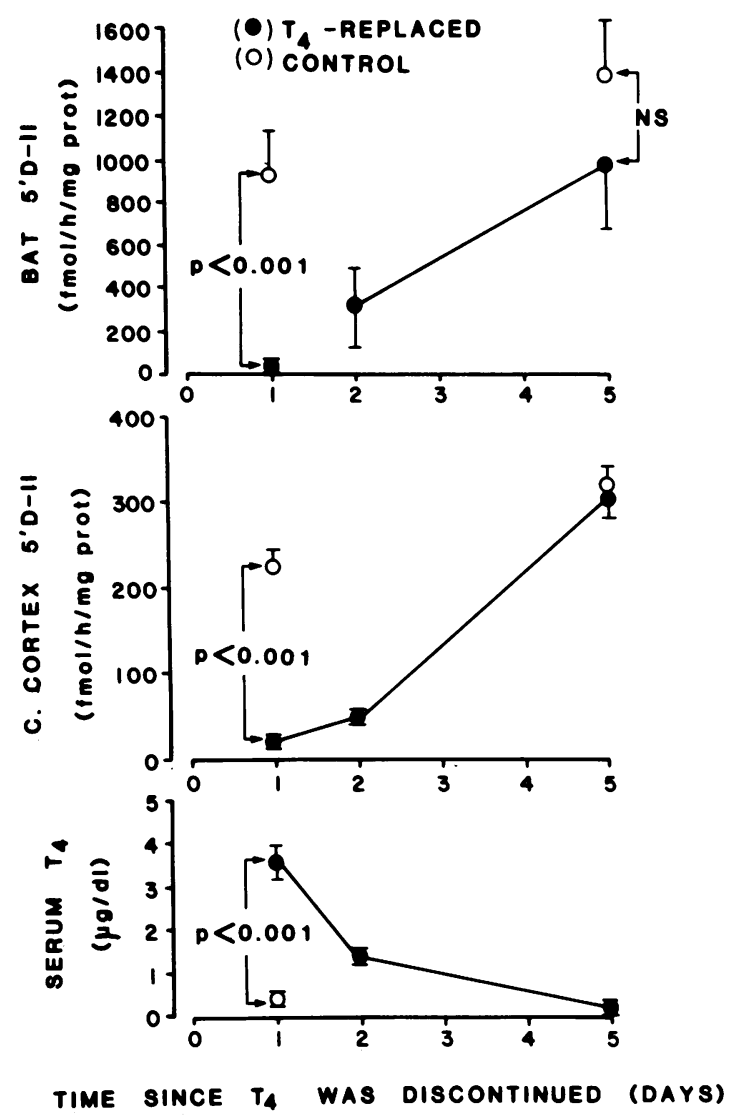

Figure 10. Response of cerebrocortical and brown adipose tissue 5 '-deiodinase to the discontinuation of $\mathrm{T}_{4}$ replacement in hypophysectomized rats. Hypophysectomized rats were given $0.8 \mu \mathrm{g}$ of $\mathrm{T}_{4} / 100 \mathrm{~g}$ BW subcutaneously daily starting $18 \mathrm{~d}$ after surgery. Replacement was maintained for a week while the rats were also injected subcutaneously with corticosterone $1 \mathrm{mg} / 100 \mathrm{~g} \mathrm{BW}$. 5D-II was measured simultaneously on samples collected at various times after the last injection of $T_{4}$.

along with the 3-4-d interval required for the enzyme to increase after hypophysectomy, suggested that the effect of GH was mediated through an intermediate step that had a longer half-life than the hormone itself. Chronically hypothyroid rats are markedly deficient in $\mathrm{GH}$, but it requires several weeks after thyroidectomy for $\mathrm{GH}$ and insulinlike growth factors to fall $(37,38)$. These data, hence, suggest that GH deficiency contributes importantly to the elevated levels of BAT 5'D-II in hypothyroid rats and also explains why it takes several weeks for the BAT 5 'D-II to become elevated after thyroidectomy. Also consistent with this view are the observations that $\mathrm{GH}$ reduced BAT 5 'DII levels in hypothyroid rats and that the elevation of BAT 5'DII mirrored the slowing of the growth rate in MMI-treated rats.

Although we did not completely exclude the participation of other pituitary-dependent mechanisms on the tonic inhibition of BAT 5'D-II, the evidence accumulated suggests that their effect, if any, is much less than that of GH. Thus, the elevation of BAT 5'D-II, both after thyroidectomy and hypophysectomy, was observed in immature males, which suggests that the tonic inhibition is not mediated through the pituitary-gonadal axis. Along the same lines, we have observed equal responses of the enzyme to cold stress and NE in immature and sexually mature males and females (results not shown). The possibility that ACTH itself, not through the adrenal cortex, exerted some in- hibitory action seem unlikely because adrenalectomized rats have not shown an increment in BAT enzyme activity (data not shown), and no persistent elevation of $\mathrm{ACTH}$ has been reported in animals following thyroidectomy. The role of endogenous opiates also seems unlikely because the injection of naloxone to rats $18-22 \mathrm{~h}$ after thyroidectomy was not followed by an increment in BAT 5'D-II, although we did not exclude the possibility that the effect of endogenous opiates was mediated through a long-lived messenger. Lastly, the possibility that there is a marked sympathetic activation after hypophysectomy that does not follow the thyroidectomy also seems unlikely in that the treatment of hypophysectomized rats with $\alpha$-methyl $p$-tyrosine for $30 \mathrm{~h}$ did not induce a reduction in the enzyme activity (data not shown), whereas this treatment prevents the cold-induced activation of BAT 5'D-II (22).

Although the conclusion that the pituitary gland exerts a tonic inhibitory control on BAT 5'D-II largely through $\mathrm{GH}$, is well supported, it seems evident that there are intermediate steps involved. Serum GH has a very short half-life, but the bioassayable sulfation factor, takes $\sim 24 \mathrm{~h}$ to disappear after hypophysectomy (39). This factor, or a similar one dependent on GH, may explain the 3-4-d delay in the elevation of the enzyme after hypophysectomy (Fig. 7). This view is consistent with our findings in rats given MMI. Within a week, the serum levels of $\mathrm{T}_{4}$ and $\mathrm{T}_{3}$ had reached a nadir and the pituitary content of $\mathrm{GH}$ had been markedly reduced. However, it was not until the third week of methimazole that the rate of weight gain was significantly reduced, suggesting that $\mathrm{GH}$-dependent growth factors or their effects take much longer to dissipate than does the primary signal. This interpretation is supported by data of Burstein et al. (38) who showed that it took several weeks after the level of $\mathrm{T}_{4}$ became undetectable, to see a marked reduction in the levels of insulinlike growth factor (IGF). In their experiments the weight of the animals correlated closely with the serum IGF concentration. Our data are also consistent with those of Coiro et al. (37), who reported that the pituitary GH levels become significantly reduced about a week after thyroidectomy. Also interesting in this study was that the reduction in the pituitary GH was not reflected in the serum GH levels until about a week later, suggesting that the secretion rate of GH may be maintained in spite of reduced pituitary GH stores. This may be another factor contributing to a delay in the reduction of the tonic pituitary-dependent suppression of BAT 5'D-II. This may be reflected in the sustained growth rate we observed 1 and 2 wk after MMI, times at which the pentobarbital-stimulated serum GH had decreased markedly. Coiro et al. (37) also found that the rate of gain in body weight in growing rats decreases significantly only 7-10 d after thyroidectomy which is consistent with our findings, given the slower onset of hypothyroidism after the administration of antithyroid drugs. Altogether, these data suggest that the failure of BAT $5^{\prime} \mathrm{D}$ II to increase after thyroidectomy is due to the delayed disappearance of $\mathrm{GH}$ and $\mathrm{GH}$-related factors, probably IGF.

The increment in cerebrocortical 5'D-II after thyroidectomy is due to a prolongation of the half-life of the active enzyme (27). For this increase to take place in 1-2 d the turnover of the enzyme must be rapid. The rapid increase in BAT 5'D-II after hypophysectomy requires that the animals receive $5 \%$ glucose in the drinking water. Studies in progress demonstrate that both insulin and glucagon can stimulate the BAT 5'D-II independently (Silva, Larsen, manuscript in preparation). An inclusive hypothesis would be that after the disappearance of $\mathrm{GH}$ (or GHdependent growth factors), BAT 5'D-II becomes more sensitive 
to the stimulatory effects of insulin and glucagon. Such an increased sensitivity of BAT to insulin, glucagon, or other stimulatory factors can certainly explain the marked increase in BAT 5'D-II 5 days after hypophysectomy. The failure of the enzyme to rise in BAT immediately after thyroidectomy can also be explained by the presence of the pituitary per se because in $\mathrm{T}_{4}$ replaced hypophysectomized animals, the withdrawal of this hormone is followed by a rapid increment in the enzyme activity. During chronic hypothyroidism, assignment of relative weights to the influence of deficiencies in tonic inhibitors such as growth hormone and $\mathrm{T}_{4}$, versus that of stimulators such as insulin, glucagon, and the sympathetic nervous system as causes for the $20-100$-fold increase in BAT $5^{\prime} \mathrm{D}$-II is difficult. For example, NE turnover in cardiac muscle is increased in chronic hypothyroidism (40), and plasma NE is also increased in this circumstance $(41,42)$. The present results only indicate that lack of $\mathrm{T}_{4}$, both because of its "specific" effect on enzyme turnover and as the precursor of the metabolic stimulator $\mathrm{T}_{3}$, and " $\mathrm{GH}$ deficiency" are contributing to this phenomenon.

An important physiologic implication of the delayed response of BAT 5'D-II to the removal of thyroid hormone in otherwise intact animals is that this tissue would not contribute significantly to the $T_{3}$ pool at early stages of hypothyroxinemia. During the days after a decrease in serum $\mathrm{T}_{4}$ levels, as occur after MMI or after starting an iodine-deficient diet, thyroidal $T_{3}$ secretion, driven by the increased levels of TSH, is the main mechanism maintaining serum $T_{3}$ levels (Larsen et al. [1] for review). It is in animals with medium- to long-term hypothyroidism where the increased fractional rate of $\mathrm{T}_{4}$ to $\mathrm{T}_{3}$ conversion by $5^{\prime} \mathrm{D}$-II occurs, which may reflect the participation of the BAT enzyme (21).

In summary, in spite of the similarities between the type II 5 -deiodinase of the BAT and that of the cortex and the pituitary gland at an enzyme kinetic level, the physiologic regulation differs markedly. In all tissues the fractional turnover rate of the enzyme is accelerated by $\mathrm{T}_{4}$ and other iodothyronines in such a way that the steady-state levels of enzyme activity in euthyroidism are only a minor fraction of the levels seen in hypothyroidism. However, whereas in the pituitary and central nervous system the turnover of the enzyme is maintained solely by $\mathrm{T}_{4}$, this does not seem to be the case in BAT, where there are many other signals regulating the expression of the enzyme, either by maintaining tonic inhibition or by stimulation.

Much evidence has been adduced in recent years that points to BAT as an important organ in nonshivering thermogenesis in animals, in the newborn human, and perhaps in the adult as well. Diet-induced BAT thermogenesis, also mediated by the sympathetic nervous system, may be important in the maintenance of normal weight (43). The increase in local and systemic $\mathrm{T}_{3}$ production by BAT 5'D-II after cold exposure (23) is physiologically sound in that both the sympathetic stimulation and the extra $T_{3}$ will contribute to heat production. It is interesting to note that in the genetically obese ob/ob mouse, neither the thermogenic nor the 5'D-II response of BAT to sympathetic stimulation is observed (44). Although the role of increased BAT 5'D-II in hypothyroidism can be readily viewed as a compensatory mechanism, the physiologic role of the dual tonic suppression by $\mathrm{T}_{4}$ and $\mathrm{GH}$ are not as easy to explain. Because the enzyme can be markedly stimulated by the sympathetic nervous system and also by insulin and glucagon the dual negative control may be a device to control its activity more finely allowing at the same time a wider response under extreme circumstances.
Certainly more work will be necessary to unravel these complex interrelationships. Furthermore, the multiplicity of perturbations in other hormone systems after endocrine manipulations raises the possibility of secondary effects, i.e., effects mediated through the action of the hormones in other systems or interactions among the hormones themselves at different levels. To clarify the interpretation of these events, it will be mandatory to have available an in vitro system to differentiate primary from secondary and tertiary effects. Notwithstanding, the present results show that the $5^{\prime}$-iodothyronine deiodinase of the brown adipocyte is a target for many of the hormone regulating metabolic processes in humans. As such, it promises to serve an important function as a model for understanding synergistic and antagonistic actions between these fundamental hormonal systems. Given the marked effects of fluctuations in BAT $5^{\prime} \mathrm{D}-\mathrm{II}$ on BAT $T_{3}$ content and on serum $T_{3}(23)$, changes in the activity of this enzyme are physiologically important regardless whether they result from direct or indirect action of various hormones on this tissue.

\section{Acknowledgments}

The authors are indebted for the excellent technical work of Peggy Matthews and Sarah Mellen, and the secretarial work by Anne Keller and Janice Bridges. We also appreciate the generous gift of bovine prolactin, bovine GH and rat GH by the National Pituitary Agency, and prazosin by Pfizer Laboratories.

This work was partially supported by grant AM-18616 from the National Institute of Arthritis, Digestive Diseases and Kidney.

\section{References}

1. Larsen, P. R., J. E. Silva, and M. M. Kaplan. 1981. Relationships between circulating and intracellular thyroid hormones: physiological and clinical implications. Endocr. Rev. 2:87-102.

2. Schwartz, H. L., M. I. Surks, and J. H. Oppenheimer. 1971. Quantitation of extrathyroidal conversion of L-thyroxine to 3,5,3'-triiodo-Lthyronine in the rat. J. Clin. Invest. 50:1124-1130.

3. DiStefano, J. J. III, M. Jang, T. K. Malone, and M. Broutman. 1982. Comprehensive kinetics of triiodothyronine production, distribution and metabolism in blood and tissue pools of the rat using optimized blood-sampling protocols. Endocrinology. 110:198-213.

4. Surks, M. I., A. R. Schadlow, J. M. Stock, and J. H. Oppenheimer. 1973. Determination of iodothyronine absorption and conversion of $1-$ thyroxine $\left(\mathrm{T}_{4}\right)$ to l-triiodothyronine $\left(\mathrm{T}_{3}\right)$ using turnover rate techniques. J. Clin. Invest. 52:805-811.

5. Visser, T. J., I. Van der Does-Tobe, R. Docter, and G. Hennemann. 1975. Conversion of thyroxine into triiodothyronine by rat liver homogenates. Biochem. J. 150:489-493.

6. Chopra, I. J. 1977. A study of extrathyroidal conversion of thyroxine $\left(\mathrm{T}_{4}\right)$ to $3,3^{\prime}, 5$-triiodothyronine $\left(\mathrm{T}_{3}\right)$ in vitro. Endocrinology. 101: 453-463.

7. Leonard, J. L., and I. N. Rosenberg. 1978. Thyroxine 5'-deiodinase activity of rat kidney: observations on activation by thiols and inhibition by propylthiouracil. Endocrinology. 103:2137-2144.

8. Kaplan, M. M., and R. D. Utiger. 1978. Iodothyronine metabolism in rat liver homogenates. J. Clin. Invest. 61:459-471.

9. Kaplan, M. M., and R. D. Utiger. 1978. Iodothyronine metabolism in liver and kidney homogenates from hyperthyroid and hypothyroid rats. Endocrinology. 103:156-161.

10. Silva, J. E., and P. R. Larsen. 1978. Contributions of plasma triiodothyronine and local thyroxine monodeiodination to triiodothyronine and nuclear triiodothyronine receptor saturation in pituitary, liver and kidney of hypothyroid rats: further evidence relating saturation of pituitary nuclear triiodothyronine receptors and the acute inhibition of thyroid-stimulating hormone release. J. Clin. Invest. 61:1247-1259. 
11. Goodman, M. N., P. R. Larsen, M. M. Kaplan, T. T. Aoki, V. R. Young, and N. B. Ruderman. 1980. Starvation in the rat. II. Effect of age and obesity on protein sparing and fuel metabolism. Am. J. Physiol. 239:E277-E286.

12. Crantz, F. R., and P. R. Larsen. 1980. Rapid thyroxine to 3,5,3'triiodothyronine conversion and nuclear 3,5,3'-triiodothyronine binding in rat cerebral cortex and cerebellum. J. Clin. Invest. 65:935-938.

13. Visser, T. J., J. L. Leonard, M. M. Kaplan, and P. R. Larsen. 1982. Kinetic evidence suggesting two mechanisms for iodothyronine 5 '-deiodination in rat cerebral cortex. Proc. Natl. Acad. Sci. USA. 79: 5080-5084.

14. Visser, T. J., M. M. Kaplan, J. L. Leonard, P. R. Larsen. 1983. Evidence for two pathways of iodothyronine 5'-deiodination in rat pituitary that differ in kinetics, propylthiouracil sensitivity, and response to hypothyroidism. J. Clin. Invest. 71:992-1002.

15. Silva, J. E., J. L. Leonard, F. R. Crantz, and P. R. Larsen. 1982. Evidence for two tissue specific pathways for in vivo thyroxine $5^{\prime}$ deiodination in the rat. J. Clin. Invest. 69:1176-1184.

16. Leonard, J. L., S. A. Mellen, and P. R. Larsen. 1982. Thyroxine 5'-deiodinase activity in brown adipose tissue. Endocrinology. 112:11531155.

17. Kaplan, M. M., and E. A. Shaw. 1984. Type II iodothyronine 5 -deiodination by human and rat placenta in vitro. J. Clin. Endocrinol. Metab. 59:253-257.

18. Silva, J. E., and J. L. Leonard. 1985. Regulation of rat cerebrocortical and adenohypophyseal type II 5 '-deiodinase by thyroxine, triiodothyronine, and reverse triiodothyronine. Endocrinology. 116:16271635.

19. Silva, J. E., and P. S. Matthews. 1984. Production rates and turnover of triiodothyrone in rat-developing-cerebral cortex and cerebellum: responses to hypothyroidism. J. Clin. Invest. 74:1035-1049.

20. Silva, J. E., and P. S. Matthews. 1984. Thyroid hormone metabolism and the sources of plasma triiodothyronine in 2-week old rats: effects of thyroid status. Endocrinology. 114:2394-2405.

21. Silva, J. E., M. B. Gordon, F. R. Crantz, J. L. Leonard, and P. R. Larsen. 1984. Qualitative and quantitative differences in the pathways of extrathyroidal $\mathrm{T}_{3}$ generation between euthyroid and hypothyroid rats. J. Clin. Invest. 73:898-907.

22. Silva, J. E., and P. R. Larsen. 1983. Adrenergic activation of triiodothyronine production in brown adipose tissue. Nature (Lond.). 305:712-713.

23. Silva, J. E., and P. R. Larsen. 1985. Potential of brown adipose tissue type II $\mathrm{T}_{4} 5^{\prime}$ deiodinase as a local and systemic source of triiodothyronine in rats. J. Clin. Invest. 76:2296-2305.

24. Himms-Hagen, J. 1984. Thyroid hormones and thermogenesis. In Mammalian Thermogenesis. L. Girardier and M. J. Stock, editors. Chapman and Hall, London. 141-177.

25. Weeke, J., and H. Orskov. 1973. Synthesis of $125 \mathrm{I}$ monolabeled 3,5,3'-triiodothyronine and thyroxine of maximum specific activity for radioimmunoassay. Scand. J. Clin. Lab. Invest. 32:357-360.

26. Kochupillai, N., and R. S. Yalow. 1978. Preparation, purification, and stability of high specific activity ${ }^{125}$ I-labeled thyronines. Endocrinology. 102:128-135.

27. Leonard, J. L., J. E. Silva, M. M. Kaplan, S. Mellen, T. J. Visser, and P. R. Larsen. 1984. Acute post-transcriptional regulation of cerebrocortical and pituitary iodothyronine 5'-deiodinase by thyroid hormone. Endocrinology. 114:998-1004.
28. Goswami, A., and I. N. Rosenberg. 1985. Iodothyronine 5'deiodinase (5'D-I) in brown adipose tissue of hypothyroid rats: activation by dithiothreitol and inhibition by propylthiouracil. Proceedings of the 67th Annual Meeting of the Endocrine Society, Baltimore. Endocrine Society, Bethesda, MD. 278. (Abstr. 1109)

29. Obregon, M. J., P. R. Larsen, J. E. Silva. 1985. Plasma kinetics, tissue distribution and cerebrocortical sources of reverse $T_{3}$ in the rat. Endocrinology. 116:2192-2200.

30. Silva, J. E., and P. R. Larsen. 1982. Comparison of iodothyronine 5 -deiodinase and other thyroid-hormone-dependent enzyme activities in the cerebral cortex of hypothyroid neonatal rat: evidence for adaptation to hypothyroidism. J. Clin. Invest. 70:1110-1123.

31. Lee, Y. P., and H. Lardy. 1965. Influence of thyroid hormones on l- $\alpha$-glycerophosphate. J. Biol. Chem. 240:1427-1436.

32. Gardner, R. S. 1974. A sensitive colorimetric assay for mitochondrial $\alpha$-glycerophosphate dehydrogenase. Anal. Biochem. 59:272276.

33. Larsen, P. R., M. Castonguay, and R. Jove. 1980. Direct radioimmunoassay quantitation of the contribution of intracellular $T_{4}$ to $\mathrm{T}_{3}$ conversion to anterior pituitary nuclear $\mathrm{T}_{3}$ in euthyroid rats. Thyroid Res. VIII, Proceedings of the Eighth International Thyroid Congress. 437-440.

34. Hervas, F., G. Morreale de Escobar, and F. Escobar del Rey. 1975. Rapid effects of single small doses of L-thyroxine and triiodo-Lthyronine on growth hormone, as studied in the rat by radioimmunoassay. Endocrinology. 97:91.

35. Armitage, P. 1971. Statistical Methods in Medical Research. John Wiley and Sons, New York.

36. Leonard, J. L., M. M. Kaplan, T. J. Visser, J. E. Silva, and P. R. Larsen. 1981. Cerebral cortex responds rapidly to thyroid hormones. Science (Wash. DC). 214:571-573.

37. Coiro, V., L. E. Braverman, D. Christianson, S. Fang, and H. M. Goodman. 1979. Effect of hypothyroidism and thyroxine replacement on growth hormone in the rat. Endocrinology. 105:641-646.

38. Burstein, P. J., B. Draznin, C. J. Johnson, and D. S. Schalch. 1979. The effect of hypothyroidism on growth, serum growth hormone, the growth hormone-dependent somatomedin, insulin-like growth factor, and its carrier protein in rats. Endocrinology. 104:1107-1111.

39. Daughaday, W. H., J. N. Heins, L. Srivastava, and C. Hammer. 1968. Sulfation factor: studies of its removal from plasma and metabolic fate in cartilage. J. Lab. Clin. Med. 72:803-811.

40. Landsberg, L., and J. Axelrod. 1968. Influence of pituitary, thyroid, and adrenal hormones on norepinephrine turnover. Circ. Res. 22: 559-571.

41. Coulombe, P., J. H. Dussault, J. Letarte, and S. J. Simard. 1976. Catecholamines metabolism in thyroid disease. I. Epinephrine secretion rate in hyperthyroidism and hypothyroidism. J. Clin. Endocrinol. Metab. 42:125-131.

42. Coulombe, P., J. H. Dussault, and P. Walker. 1977. Catecholamine metabolism in thyroid disease. II. Norepinephrine secretion rate in hyperthyroidism and hypothyroidism. J. Clin. Endocrinol. Metab. 44: 1185-1189.

43. Himms-Hagen, J. 1984. Thermogenesis in brown adipose tissue as an energy buffer: implications for obesity. N. Engl. J. Med. 311:15491558

44. Kaplan, M. M., and J. B. Young. 1984. Impaired activation of brown adipose tissue iodothyronine 5 -deiodinase by cold in ob/ob mice. Clin. Res. 32:400A. (Abstr.) 